\title{
Sheet-like of $\mathrm{Mo}^{\mathrm{V}}-\mathrm{Sm}^{\mathrm{III}}$ assembly containing $\left[\mathrm{Mo}^{\mathrm{V}}(\mathrm{CN})_{8}\right]^{3-}$ and $\mathrm{Sm}^{3+}$ ions as building blocks
}

\author{
SHU-LIN MA ${ }^{1, *}$, SHI REN ${ }^{1}$, YUE MA ${ }^{2}$ and DAI-ZHENG LIAO ${ }^{2, *}$ \\ ${ }^{1}$ Department of Application Chemistry, College of Science, Tianjin University of Commerce, \\ Tianjin, 300134, PR China \\ ${ }^{2}$ Department of Chemistry, Nankai University, Tianjin, 300071, PR China \\ e-mail: mashulin@tjcu.edu.cn; liaodz@nankai.edu.cn
}

MS received 7 February 2009; revised 2 April 2009; accepted 13 May 2009

\begin{abstract}
The reaction of $\left[\mathrm{Mo}(\mathrm{CN})_{8}\right]^{3-}$ with $\mathrm{Sm}^{3+}$ and 2,2'-bipyridine (bpy) lead to a sheet-like bimetallic complex, $\left\{\mathrm{Sm}\left(\mathrm{H}_{2} \mathrm{O}\right)_{9}\left[\mathrm{Sm}_{2}(\mathrm{bpy})_{2}(\mathrm{OH})_{2.75}\left(\mathrm{NO}_{3}\right)_{0.25}\right]\left[\mathrm{Mo}(\mathrm{CN})_{8}\right]_{2}\right\}_{n}$ (1) in EtOH/H $\mathrm{H}_{2} \mathrm{O}$ mixture solvent. The complex 1 crystallizes in monoclinic, space group $C 2 / c$. The structural investigation denotes that the layers interaction with each other by $\pi-\pi$ stacks and hydrogen bonds result in a $3 \mathrm{D}$ network, containing $\mathrm{Sm}\left(\mathrm{H}_{2} \mathrm{O}\right)_{9}^{3+}$ as guest molecules in the holes. The magnetic behaviour of the complex $\mathbf{1}$ has been studied.
\end{abstract}

Keywords. Cyano bridges; ferromagnetic coupling; $\pi-\pi$ stacks; 3D network structure.

\section{Introduction}

There has been a growing interest in the preparation of molecule-based magnet in recent years. ${ }^{1-7}$ The hexacyanometalate ions, acting as good building units, have been successfully utilized to obtain a large number of one-, two-, and three-dimensional cyano-bridged assemblies with high magnetic ordering temperature and interesting architectures. ${ }^{8-11}$ Recently, octacyanometallate-based magnets have also drawn much attention. $\left[\mathrm{M}^{\mathrm{V}}(\mathrm{CN})_{8}\right]^{3-}(\mathrm{M}=\mathrm{Mo}$, $\mathrm{W})$, etc. is a versatile class of building blocks that can adopt different spatial configurations, just as square antiprism $\left(D_{4 \mathrm{~d}}\right)$, dodecahedron $\left(D_{2 \mathrm{~d}}\right)$, and bicapped trigonal prism $\left(C_{2 \mathrm{v}}\right)$. Because of their enhanced exchange interaction in bimetallic compounds based on large extended of $4 d$ or $5 d$ magnetic orbitals, $\left[\mathrm{M}^{\mathrm{V}}(\mathrm{CN})_{8}\right]^{3-}(\mathrm{M}=\mathrm{Mo}$ and $\mathrm{W})$ are a kind of good precursors in magnetic materials. Following the pioneering work of Kahn's group, ${ }^{12-14}$ these flexible species may be used as versatile synthons to construct a variety of architectures or networks with novel topological structures and interesting magnetic properties. For example, $\mathbf{M}^{\mathrm{V}}-\mathrm{Mn}^{\mathrm{II}}{ }^{15-23} \mathbf{M}^{\mathrm{V}}-$ $\mathrm{Cu}^{\text {II } 24-34} \mathrm{M}^{\mathrm{V}}-\mathrm{Co}^{\text {II }}{ }^{35-38} \mathrm{M}^{\mathrm{V}}-\mathrm{Ni}^{\text {II }}{ }^{39-41} \mathrm{M}_{6}^{\mathrm{V}} \mathrm{Mn}_{9}{ }_{9}^{\text {II }}{ }^{36,40-45}$ $(\mathrm{M}=\mathrm{Mo}$ and $\mathrm{W})$ bimetallic assemblies with a variety of extended structure, have been obtained. However,

*For correspondence the syntheses of complexes containing octacyanometallate $(\mathrm{V})$ and lanthanide ions are still relatively challenging. To the best of our knowledge, metal assemblies based on $\left[\mathrm{M}^{\mathrm{V}}(\mathrm{CN})_{8}\right]^{3-}(\mathrm{M}=\mathrm{Mo}$ or W) with lanthanide ions can take various geometries in the crystal structure, e.g. with one-dimensional (1D) ${ }^{46-51}$ and two-dimensional (2D) $)^{52,53}$ assemblies. Among these dimensionalities, there are only three complexes, $\left[\mathrm{Tb}^{\mathrm{III}}(\text { pzam })_{3}\left(\mathrm{H}_{2} \mathrm{O}\right) \mathrm{Mo}^{\mathrm{V}}(\mathrm{CN})_{8}\right]$. $\mathrm{H}_{2} \mathrm{O}^{46} \quad$ (pzam = pyrazine-2-carboxamide), $\left\{\left[\mathrm{Gd}^{\mathrm{II}}\right.\right.$ $\left.\left.(\mathrm{DMF})_{4}(\mathrm{MeOH})_{2}\right]\left[\mathrm{Mo}^{\mathrm{V}}(\mathrm{CN})_{8}\right]\right\}_{n}^{51}$ and $\mathrm{Tb}^{\mathrm{III}}\left(\mathrm{H}_{2} \mathrm{O}\right)_{5}$ $\left[\mathrm{Mo}^{\mathrm{V}}(\mathrm{CN})_{8}\right],{ }^{53}$ based on anionic octacyanomolybdate $(\mathrm{V})$ with rare earth ions. In search of new materials of $4 d-4 f$ cyanide-bridged assemblies from $\left[\mathrm{Mo}(\mathrm{CN})_{8}\right]^{3-}$ building blocks, this paper details the synthesis, characterization, and magnetic properties of octacyanomolybdate(IV)-based complex with 2D sheet-like structure, $\left\{\mathrm{Sm}\left(\mathrm{H}_{2} \mathrm{O}\right)_{9}\left[\mathrm{Sm}_{2}(\mathrm{bpy})_{2}(\mathrm{OH})_{2.75}\right.\right.$ $\left.\left.\left(\mathrm{NO}_{3}\right)_{0.25}\right]\left[\mathrm{Mo}(\mathrm{CN})_{8}\right]_{2}\right\}_{n}(\mathbf{1})$ (bpy $=2,2^{\prime}$-bipyridine).

\section{Experimental}

\subsection{Materials and methods}

The precursor $\left(n-\mathrm{Bu}_{4} \mathrm{~N}\right)_{3}\left[\mathrm{Mo}^{\mathrm{V}}(\mathrm{CN})_{8}\right] \cdot 2 \mathrm{H}_{2} \mathrm{O}$ was prepared according to literature methods. ${ }^{54}$ All other chemicals were reagent grade and can be used without further purification. Since the octacyanometalate ions have a tendency to decompose under irradia- 
tion, the synthesis of the complex was performed in a dark room at room temperature.

\subsection{Preparation of $\left\{\mathrm{Sm}\left(\mathrm{H}_{2} \mathrm{O}\right)_{9}\left[\mathrm{Sm}_{2}(\mathrm{bpy})_{2}(\mathrm{OH})_{2.75}\right.\right.$} $\left.\left(\mathrm{NO}_{3}\right)_{0.25}\right]\left[\mathrm{Mo}(\mathrm{CN})_{8}\right]_{2\}_{n}}(\mathbf{1})$

To a solution of $\mathrm{Sm}\left(\mathrm{NO}_{3}\right)_{3} \cdot 6 \mathrm{H}_{2} \mathrm{O} \quad(0.2 \mathrm{mmol}$, $88.9 \mathrm{mg})$ and $\left(n-\mathrm{Bu}_{4} \mathrm{~N}\right)_{3}\left[\mathrm{Mo}(\mathrm{CN})_{8}\right] \cdot 2 \mathrm{H}_{2} \mathrm{O}(0.2 \mathrm{mmol}$, $147.8 \mathrm{mg})$ in $\mathrm{EtOH} / \mathrm{H}_{2} \mathrm{O}(1: 1,8 \mathrm{~mL})$ was added a solution of bipyridine $(0.6 \mathrm{mmol}, 93.6 \mathrm{mg})$ in ethanol $(2 \mathrm{~mL})$. The reaction mixture was stirred for $5 \mathrm{~min}$ at room temperature, and then filtered. Slow evaporation of the filtrate led to the formation of yellow crystals. Yield: ca $28 \%$. Anal Calcd for $\mathrm{C}_{36} \mathrm{H}_{36.50} \mathrm{Mo}_{2} \mathrm{~N}_{20.50} \mathrm{O}_{14} \mathrm{Sm}_{3}: \mathrm{C}, 26.63 ; \mathrm{H}, 2.27 ; \mathrm{N}$, $17.69 \%$. Found: C, $26.58 ; \mathrm{H}, 2.56$; N, $17.56 \%$. IR data $\left(\mathrm{cm}^{-1}, \mathrm{KBr}\right.$ pellets $): 2120 v(\mathrm{C} \equiv \mathrm{N})$.

\subsection{Physical measurements}

Elemental analyses for $\mathrm{C}, \mathrm{H}$, and $\mathrm{N}$ were carried out on a Perkin-Elmer elemental analyzer (model 240). The infrared spectrum was obtained on a Bruker Tensor 27 Fourier transform infrared spectroscopy in the $4000-400 \mathrm{~cm}^{-1}$ region, using $\mathrm{KBr}$ pellets. Variable temperature magnetic susceptibilities were measured on SQUID magnetometer from 2.0 to
$300 \mathrm{~K}$ in a magnetic field of $2000 \mathrm{Oe}$, and the diamagnetic corrections were applied by using Pascal's constants.

\section{$2.4 \quad X$-ray data collections and structure determinations}

All measurements were made on a Rigaku Saturn CCD area detector with graphite monochromated Mo-K $\alpha$ radiation $(\lambda=0.71070 \AA)$. The empirical absorption corrections by semi-empirical from equivalents were carried out. The structure was solved by direct methods using the SHELXS-97 $\operatorname{program}^{55}$ and refined with SHELXL-97 ${ }^{55}$ by fullmatrix least-squares techniques on $F^{2}$. All nonhydrogen atoms were refined anisotropically, while the hydrogen atoms were located geometrically and refined isotropically. Further details of the structure analysis are given in table 1 .

\section{Results and discussion}

\subsection{General properties}

A bimetallic complex 1 has been synthesized, and fully characterized by elemental analysis, IR spectroscopy, and X-ray crystallography. The most feature

Table 1. Crystallographic data and structure refinement for 1 .

\begin{tabular}{ll}
\hline Empirical formula & $\mathrm{C}_{36} \mathrm{H}_{38 \cdot 50} \mathrm{Mo}_{2} \mathrm{~N}_{20 \cdot 50} \mathrm{O}_{14} \mathrm{Sm}_{3}$ \\
$F \mathrm{w}$ & $1625 \cdot 30$ \\
Temperature (K) & $293(2)$ \\
$\lambda(\AA)$ & $0 \cdot 71070$ \\
Cryst. syst. & Monoclinic \\
Space group & $C 2 / c$ \\
$a, b, c(\AA)$ & $25 \cdot 784(2), 11 \cdot 0630(10), 21 \cdot 5080(18)$ \\
$\beta\left({ }^{\circ}\right)$ & $123 \cdot 864(8)$ \\
$V\left(\AA^{3}\right)$ & $5094 \cdot 4(7)$ \\
$\rho\left(\mathrm{g} / \mathrm{cm}^{3}\right)$ & $2 \cdot 119$ \\
$Z$ & 4 \\
$\mu\left(\mathrm{mm}^{-1}\right)$ & $3 \cdot 965$ \\
$F(000)$ & 3120 \\
Crystal size (mm) & $0 \cdot 20 \times 0 \cdot 20 \times 0 \cdot 20$ \\
Theta range for data collection $\left(^{\circ}\right)$ & $1 \cdot 90$ to $25 \cdot 01$ \\
Limiting indices & $-30 \leq h \leq 30,-13 \leq k \leq 13,-25 \leq 1 \leq 25$ \\
Reflections collected/unique & $25234 / 4490\left(R_{\text {int }}=0 \cdot 0441\right)$ \\
Completeness to theta $=25 \cdot 01$ & $100 \cdot 0 \%$ \\
Max. and min. transmission & $0 \cdot 810$ and $0 \cdot 716$ \\
Refinement method & Full-matrix least-squares on $F^{2}$ \\
Data/restraints/parameters & $4490 / 51 / 362$ \\
Goodness-of-fit on $F^{2}$ & $1 \cdot 097$ \\
Final $R$ indices $[I>2 \sigma(I)]$ & $R_{1}=0 \cdot 0453, w R_{2}=0 \cdot 1233$ \\
$R$ indices (for all data) & $R_{1}=0 \cdot 0474, w R_{2}=0 \cdot 1247$ \\
Largest diff. peak and hole $\left(\mathrm{e} / \mathrm{A}^{3}\right)$ & $2 \cdot 200$ and $-4 \cdot 200$ \\
\hline
\end{tabular}


Table 2. Selected bond lengths $(\AA)$ and angles (deg) for the complex $\mathbf{1}$.

\begin{tabular}{|c|c|c|c|}
\hline $\mathrm{Mo}(1)-\mathrm{C}(4)$ & $2 \cdot 143(9)$ & $\mathrm{Sm}(1)-\mathrm{O}(1)$ & $2 \cdot 461(5)$ \\
\hline $\mathrm{Mo}(1)-\mathrm{C}(7) \# 1$ & $2 \cdot 153(8)$ & $\operatorname{Sm}(1)-N(6)$ & $2 \cdot 492(7)$ \\
\hline $\mathrm{Mo}(1)-\mathrm{C}(2)$ & $2 \cdot 155(7)$ & $\operatorname{Sm}(1)-N(7)$ & $2 \cdot 507(7)$ \\
\hline $\mathrm{Mo}(1)-\mathrm{C}(6) \# 2$ & $2 \cdot 161(8)$ & $\operatorname{Sm}(1)-N(8)$ & $2 \cdot 509(7)$ \\
\hline $\mathrm{Mo}(1)-\mathrm{C}(1)$ & $2 \cdot 167(8)$ & $\operatorname{Sm}(1)-N(1)$ & $2 \cdot 525(7)$ \\
\hline $\mathrm{Mo}(1)-\mathrm{C}(8) \# 3$ & $2 \cdot 170(9)$ & $\operatorname{Sm}(1)-N(11)$ & $2 \cdot 564(6)$ \\
\hline $\mathrm{Mo}(1)-\mathrm{C}(3)$ & $2 \cdot 171(8)$ & $\operatorname{Sm}(1)-N(10)$ & $2 \cdot 568(7)$ \\
\hline $\mathrm{Mo}(1)-\mathrm{C}(5)$ & $2 \cdot 175(8)$ & & \\
\hline $\mathrm{C}(1)-\mathrm{Mo}(1)-\mathrm{C}(3)$ & $77 \cdot 7(3)$ & $\mathrm{N}(7)-\mathrm{C}(7)-\mathrm{Mo}(1) \# 5$ & $176 \cdot 7(7)$ \\
\hline $\mathrm{C}(1)-\mathrm{Mo}(1)-\mathrm{C}(5)$ & $143 \cdot 2(3)$ & $\mathrm{N}(8)-\mathrm{C}(8)-\mathrm{Mo}(1) \# 3$ & $176 \cdot 7(8)$ \\
\hline $\mathrm{C}(2)-\mathrm{Mo}(1)-\mathrm{C}(1)$ & $74 \cdot 5(3)$ & $\mathrm{C}(1)-\mathrm{N}(1)-\mathrm{Sm}(1)$ & $155 \cdot 1(6)$ \\
\hline $\mathrm{C}(2)-\mathrm{Mo}(1)-\mathrm{C}(3)$ & $72 \cdot 4(3)$ & $\mathrm{C}(6)-\mathrm{N}(6)-\mathrm{Sm}(1)$ & $152 \cdot 4(6)$ \\
\hline $\mathrm{C}(2)-\mathrm{Mo}(1)-\mathrm{C}(5)$ & $130 \cdot 1(3)$ & $\mathrm{C}(7)-\mathrm{N}(7)-\mathrm{Sm}(1)$ & $157 \cdot 7(6)$ \\
\hline $\mathrm{C}(3)-\mathrm{Mo}(1)-\mathrm{C}(5)$ & $131 \cdot 4(3)$ & $\mathrm{C}(8)-\mathrm{N}(8)-\mathrm{Sm}(1)$ & $167 \cdot 9(7)$ \\
\hline $\mathrm{C}(4)-\mathrm{Mo}(1)-\mathrm{C}(1)$ & $71 \cdot 2(3)$ & $\mathrm{C}(9)-\mathrm{N}(10)-\mathrm{Sm}(1)$ & $120 \cdot 7(5)$ \\
\hline $\mathrm{C}(4)-\mathrm{Mo}(1)-\mathrm{C}(2)$ & $132 \cdot 9(3)$ & $\mathrm{C}(13)-\mathrm{N}(10)-\mathrm{Sm}(1)$ & $122 \cdot 0(5)$ \\
\hline $\mathrm{C}(4)-\mathrm{Mo}(1)-\mathrm{C}(3)$ & $128 \cdot 2(3)$ & $\mathrm{C}(14)-\mathrm{N}(11)-\mathrm{Sm}(1)$ & $121 \cdot 9(5)$ \\
\hline $\mathrm{C}(4)-\mathrm{Mo}(1)-\mathrm{C}(5)$ & $72 \cdot 4(3)$ & $\mathrm{C}(18)-\mathrm{N}(11)-\mathrm{Sm}(1)$ & $119 \cdot 6(5)$ \\
\hline $\mathrm{C}(4)-\mathrm{Mo}(1)-\mathrm{C}(7) \# 1$ & $142 \cdot 0(3)$ & $\mathrm{O}(1)-\mathrm{Sm}(1)-\mathrm{N}(1)$ & $73 \cdot 4(2)$ \\
\hline $\mathrm{C}(1)-\mathrm{Mo}(1)-\mathrm{C}(8) \# 3$ & $89 \cdot 4(3)$ & $\mathrm{O}(1)-\mathrm{Sm}(1)-\mathrm{N}(6)$ & $77 \cdot 0(2)$ \\
\hline $\mathrm{C}(2)-\mathrm{Mo}(1)-\mathrm{C}(6) \# 2$ & $140 \cdot 7(3)$ & $\mathrm{O}(1)-\mathrm{Sm}(1)-\mathrm{N}(7)$ & $75 \cdot 30(19)$ \\
\hline $\mathrm{C}(2)-\mathrm{Mo}(1)-\mathrm{C}(8) \# 3$ & $71 \cdot 3(3)$ & $\mathrm{O}(1)-\mathrm{Sm}(1)-\mathrm{N}(8)$ & $79 \cdot 5(2)$ \\
\hline $\mathrm{C}(4)-\mathrm{Mo}(1)-\mathrm{C}(6) \# 2$ & $76 \cdot 4(3)$ & $\mathrm{O}(1)-\mathrm{Sm}(1)-\mathrm{N}(10)$ & $144 \cdot 1(2)$ \\
\hline $\mathrm{C}(4)-\mathrm{Mo}(1)-\mathrm{C}(8) \# 3$ & $76 \cdot 9(3)$ & $\mathrm{O}(1)-\mathrm{Sm}(1)-\mathrm{N}(11)$ & $148 \cdot 38(19)$ \\
\hline $\mathrm{C}(6) \# 2-\mathrm{Mo}(1)-\mathrm{C}(1)$ & $98 \cdot 5(3)$ & $\mathrm{N}(1)-\operatorname{Sm}(1)-\mathrm{N}(10)$ & $80 \cdot 8(2)$ \\
\hline $\mathrm{C}(6) \# 2-\mathrm{Mo}(1)-\mathrm{C}(3)$ & $68 \cdot 3(3)$ & $\mathrm{N}(1)-\operatorname{Sm}(1)-\mathrm{N}(11)$ & $138 \cdot 0(2)$ \\
\hline $\mathrm{C}(6) \# 2-\mathrm{Mo}(1)-\mathrm{C}(5)$ & $78 \cdot 1(3)$ & $\mathrm{N}(6)-\operatorname{Sm}(1)-\mathrm{N}(1)$ & $78 \cdot 1(2)$ \\
\hline $\mathrm{C}(7) \# 1-\mathrm{Mo}(1)-\mathrm{C}(1)$ & $146 \cdot 6(3)$ & $\mathrm{N}(6)-\mathrm{Sm}(1)-\mathrm{N}(7)$ & $77 \cdot 0(2)$ \\
\hline $\mathrm{C}(7) \# 1-\mathrm{Mo}(1)-\mathrm{C}(2)$ & $75 \cdot 9(3)$ & $\mathrm{N}(6)-\operatorname{Sm}(1)-\mathrm{N}(8)$ & $147 \cdot 3(2)$ \\
\hline $\mathrm{C}(7) \# 1-\mathrm{Mo}(1)-\mathrm{C}(3)$ & $79 \cdot 0(3)$ & $\mathrm{N}(6)-\mathrm{Sm}(1)-\mathrm{N}(10)$ & $73 \cdot 5(2)$ \\
\hline $\mathrm{C}(7) \# 1-\mathrm{Mo}(1)-\mathrm{C}(5)$ & $69 \cdot 6(3)$ & $\mathrm{N}(6)-\operatorname{Sm}(1)-\mathrm{N}(11)$ & $109 \cdot 0(2)$ \\
\hline $\mathrm{C}(8) \# 3-\mathrm{Mo}(1)-\mathrm{C}(3)$ & $143 \cdot 6(3)$ & $\mathrm{N}(7)-\mathrm{Sm}(1)-\mathrm{N}(1)$ & $143 \cdot 5(2)$ \\
\hline $\mathrm{C}(8) \# 3-\mathrm{Mo}(1)-\mathrm{C}(5)$ & $77 \cdot 2(3)$ & $\mathrm{N}(7)-\mathrm{Sm}(1)-\mathrm{N}(8)$ & $75 \cdot 3(2)$ \\
\hline $\mathrm{N}(1)-\mathrm{C}(1)-\mathrm{Mo}(1)$ & $172 \cdot 6(7)$ & $\mathrm{N}(7)-\mathrm{Sm}(1)-\mathrm{N}(10)$ & $116 \cdot 5(2)$ \\
\hline $\mathrm{N}(2)-\mathrm{C}(2)-\mathrm{Mo}(1)$ & $178 \cdot 3(7)$ & $\mathrm{N}(7)-\mathrm{Sm}(1)-\mathrm{N}(11)$ & $76 \cdot 0(2)$ \\
\hline $\mathrm{N}(3)-\mathrm{C}(3)-\mathrm{Mo}(1)$ & $178 \cdot 9(7)$ & $\mathrm{N}(8)-\mathrm{Sm}(1)-\mathrm{N}(1)$ & $116 \cdot 2(2)$ \\
\hline $\mathrm{N}(4)-\mathrm{C}(4)-\mathrm{Mo}(1)$ & $177 \cdot 1(7)$ & $\mathrm{N}(8)-\mathrm{Sm}(1)-\mathrm{N}(10)$ & $135 \cdot 3(2)$ \\
\hline $\mathrm{N}(5)-\mathrm{C}(5)-\mathrm{Mo}(1)$ & $178 \cdot 8(7)$ & $\mathrm{N}(8)-\mathrm{Sm}(1)-\mathrm{N}(11)$ & $80 \cdot 7(2)$ \\
\hline $\mathrm{N}(6)-\mathrm{C}(6)-\mathrm{Mo}(1) \# 2$ & $175 \cdot 3(7)$ & $\mathrm{N}(11)-\mathrm{Sm}(1)-\mathrm{N}(10)$ & $63 \cdot 1(2)$ \\
\hline
\end{tabular}

Symmetry codes: \#1 $x,-y, z+1 / 2 ; \# 2-x+1 / 2,-y-1 / 2,-z+1 ; \# 3-x+1 / 2,-y+1 / 2$, $-z+1 ; \# 4-x, y,-z+1 / 2 ; \# 5 x,-y, z-1 / 2$

of the IR spectra concern the existence of $2120 \mathrm{~cm}^{-1}$ for 1 , which may be assigned to the characteristic $\mathrm{CN}^{-}$stretching vibrations.

\subsection{Structural description}

$\mathrm{X}$-ray single crystal analysis indicates that 1 crystallizes in monoclinic, space group $C 2 / c$, with $a=$ 25.784(2), $\quad b=11.0630(10), \quad c=21.5080(18) \AA$, $\beta=123 \cdot 864(8)^{\circ}$. Selected bond lengths and angles are listed in table 2. ORTEP view of the basic unit of 1 is shown in figure 1 . Crystal structure analysis of 1 reveals that 1 consists of a two-dimensional
(2D) cyano-bridged network, in which $\mathrm{Sm}^{\mathrm{III}}$ and $\mathrm{Mo}^{\mathrm{V}}$ ions are linked in alternating fashion, and the charge of which is balanced by the $\left[\mathrm{Sm}\left(\mathrm{H}_{2} \mathrm{O}\right)_{9}\right]^{3+}$ cation. In the complex 1 , the four $\mu$-CNs of $\left[\mathrm{Mo}(\mathrm{CN})_{8}\right]^{3-}$ are bridged to $\mathrm{Sm}^{\mathrm{III}}$ ions, respectively, and the other four are free. The $\mathrm{Sm}$ atom is surround by nitrogen atoms of four $\mu$-CNs; one bpy ligand; and a disordered group $\left[\mathrm{NO}_{3}^{-}(0.25 \%)\right.$ or $\mathrm{OH}^{-}$ $(0.75 \%)]$, respectively. It is noticed that the bond angles of $\mathrm{C}-\mathrm{N}-\mathrm{Sm}$ are far from linearity with the angles of $155 \cdot 1(6)^{\circ} \quad[\mathrm{C}(1)-\mathrm{N}(1)-\mathrm{Sm}(1)]$ and $152.4(6)^{\circ}[\mathrm{C}(6)-\mathrm{N}(6)-\mathrm{Sm}(1)]$, respectively, while the angles of $\mathrm{Mo}-\mathrm{C}-\mathrm{N}$ are almost linear, ranging 
Table 3. Selected H-bond lengths (A) for the complex 1 .

\begin{tabular}{|c|c|c|c|c|c|}
\hline Donor-H $\cdots$ Acceptor & D-H & $\mathrm{H} \cdots \mathrm{A}$ & $A \cdots D$ & $\square \mathrm{D}-\mathrm{H} \cdots \mathrm{A}$ & Symmetry code \\
\hline $\mathrm{O}(1)-\mathrm{H}(1 \mathrm{~A}) \cdots \mathrm{N}(5)$ & $0 \cdot 850$ & $2 \cdot 319$ & $2 \cdot 896$ & $125 \cdot 43$ & \multirow[t]{2}{*}{$x,-y, z-1 / 2$} \\
\hline $\mathrm{O}(1)-\mathrm{H}(1 \mathrm{~B}) \cdots \mathrm{O}(4)$ & $0 \cdot 850$ & $2 \cdot 181$ & $2 \cdot 909$ & $143 \cdot 62$ & \\
\hline $\mathrm{O}(1)-\mathrm{H}(1 \mathrm{~B}) \cdots \mathrm{O}(9)$ & $0 \cdot 850$ & $2 \cdot 366$ & $2 \cdot 868$ & $118 \cdot 32$ & \multirow{2}{*}{$-x+1 / 2,-y+1 / 2,-z+1$} \\
\hline $\mathrm{O}(1)-\mathrm{H}(1 \mathrm{~B}) \cdots \mathrm{O}(5)$ & $0 \cdot 850$ & $2 \cdot 657$ & $3 \cdot 284$ & $131 \cdot 69$ & \\
\hline $\mathrm{O}(2)-\mathrm{H}(2 \mathrm{~A}) \cdots \mathrm{N}(2)$ & 0.850 & $2 \cdot 401$ & $2 \cdot 844$ & $113 \cdot 02$ & \multirow{4}{*}{$\begin{array}{l}-x+1 / 2,-y+1 / 2,-z+1 \\
x-1 / 2,-y+1 / 2, z-1 / 2 \\
x,-y, z-1 / 2\end{array}$} \\
\hline $\mathrm{O}(2)-\mathrm{H}(2 \mathrm{~B}) \cdots \mathrm{N}(2)$ & $0 \cdot 850$ & $2 \cdot 401$ & $2 \cdot 844$ & $113 \cdot 02$ & \\
\hline $\mathrm{O}(3)-\mathrm{H}(3 \mathrm{~A}) \cdots \mathrm{N}(5)$ & $0 \cdot 850$ & $2 \cdot 244$ & $2 \cdot 864$ & $129 \cdot 82$ & \\
\hline $\mathrm{O}(4)-\mathrm{H}(4 \mathrm{~A}) \cdots \mathrm{O}(1)$ & 0.850 & $2 \cdot 393$ & $2 \cdot 909$ & $119 \cdot 70$ & \\
\hline $\mathrm{O}(4)-\mathrm{H}(4 \mathrm{~A}) \cdots \mathrm{N}(5)$ & 0.850 & $2 \cdot 635$ & $3 \cdot 460$ & $163 \cdot 83$ & \multirow{4}{*}{$\begin{array}{l}x,-y, z-1 / 2 \\
-x+1 / 2,-y+1 / 2,-z+1 \\
-x+1 / 2,-y+1 / 2,-z+1 \\
-x+1 / 2,-y-1 / 2,-z+1\end{array}$} \\
\hline $\mathrm{O}(4)-\mathrm{H}(4 \mathrm{~B}) \cdots \mathrm{N}(2)$ & $0 \cdot 850$ & $2 \cdot 145$ & $2 \cdot 823$ & $136 \cdot 61$ & \\
\hline $\mathrm{O}(4)-\mathrm{H}(4 \mathrm{~B}) \cdots \mathrm{O}(9)$ & 0.850 & $2 \cdot 473$ & $2 \cdot 920$ & $113 \cdot 67$ & \\
\hline $\mathrm{O}(5)-\mathrm{H}(5 \mathrm{~A}) \cdots \mathrm{N}(3)$ & $0 \cdot 850$ & $2 \cdot 011$ & $2 \cdot 780$ & $149 \cdot 98$ & \\
\hline $\mathrm{O}(5)-\mathrm{H}(5 \mathrm{~B}) \cdots \mathrm{N}(4)$ & $0 \cdot 850$ & 1.965 & $2 \cdot 795$ & $165 \cdot 05$ & \multirow{3}{*}{$-x+1 / 2,-y+1 / 2,-z+1$} \\
\hline $\mathrm{O}(6)-\mathrm{H}(6 \mathrm{~A}) \cdots \mathrm{O}(7)$ & $0 \cdot 850$ & $2 \cdot 316$ & $2 \cdot 762$ & $113 \cdot 04$ & \\
\hline $\mathrm{O}(6)-\mathrm{H}(6 \mathrm{~A}) \cdots \mathrm{N}(4)$ & $0 \cdot 850$ & $2 \cdot 378$ & $2 \cdot 869$ & $117 \cdot 34$ & \\
\hline $\mathrm{O}(7)-\mathrm{H}(7 \mathrm{~A}) \cdots \mathrm{O}(6)$ & 0.930 & $2 \cdot 125$ & $2 \cdot 762$ & $124 \cdot 58$ & \multirow[t]{2}{*}{$-x+1 / 2,-y+1 / 2,-z+1$} \\
\hline $\mathrm{O}(7)-\mathrm{H}(7 \mathrm{~A}) \cdots \mathrm{N}(2)$ & $0 \cdot 930$ & $2 \cdot 696$ & $3 \cdot 148$ & $110 \cdot 73$ & \\
\hline
\end{tabular}

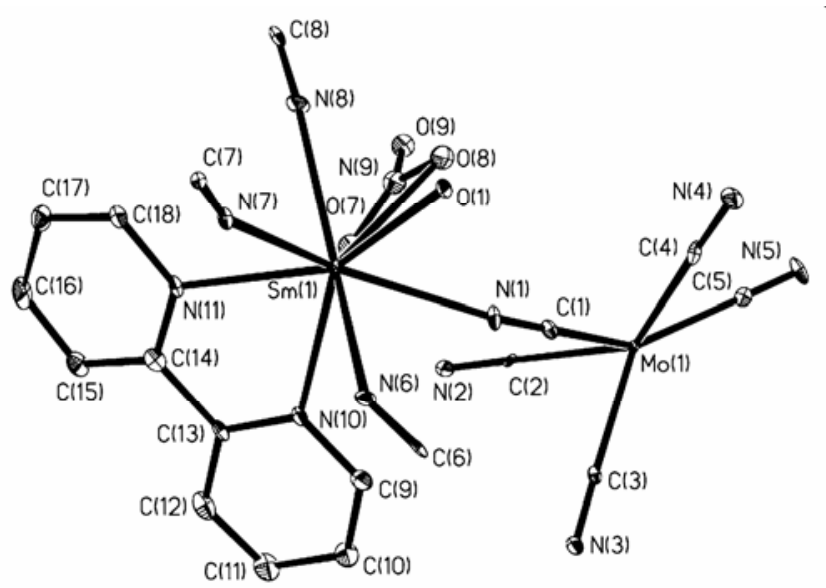

Figure 1. ORTEP view of the basic unit of 1 showing the atom-labelling scheme and ellipsoids at $30 \%$ probability. Hydrogen atoms and $\left[\mathrm{Sm}\left(\mathrm{H}_{2} \mathrm{O}\right)_{9}\right]^{3+}$ ion have been omitted for the sake of clarity.

from $172 \cdot 6(7)^{\circ}$ to $178 \cdot 8(7)^{\circ}$, in which two $\mu$-CNs are $172 \cdot 6(7)^{\circ}[\mathrm{N}(1)-\mathrm{C}(1)-\mathrm{Mo}(1)]$ and $175 \cdot 3(7)^{\circ}$ [N(6)-C(6)-Mo(1)\#2 (\#2-x+1/2,-y-1/2,-z+1)]. As shown in figure 2, the four cyanide groups of $\left[\mathrm{Mo}(\mathrm{CN})_{8}\right]^{3-}$ bridging $\mathrm{Sm}^{\text {III }}$ ions give rise to the square-grid pattern of the single layer. The intra-

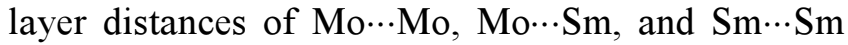
are 7.099(4), 5.6083(5), and 6.97984(4) $\AA$, respectively. In addition, the bpy ligands standing the two sides of the layer are involved in the extensive net- work of $\pi-\pi$ stacks linking parallel neighbouring layers through the aryl rings of bpy ligands (see figure 3). As shown in figure 4 , the $\left[\mathrm{Sm}\left(\mathrm{H}_{2} \mathrm{O}\right)_{9}^{3+}\right]$ as guest molecules is buried in the holes which are made by $\pi-\pi$ stacks between adjacent layers. The oxygen atoms coming from $\mathrm{Sm}(2)\left[\mathrm{Sm}\left(\mathrm{H}_{2} \mathrm{O}\right)_{9}^{3+}\right.$ ions] and $\mathrm{Sm}(1)$ atoms, respectively, connected with the nitrogen atoms of cyanide groups of the $\left[\mathrm{Mo}(\mathrm{CN})_{8}\right]^{3-}$ by hydrogen-bonds. The relevant details are shown in table 3. These weak interactions are undoubtedly significant in construction of the system. Therefore, these $2 \mathrm{D}$ sheets owing to the $\pi-\pi$ stacks and hydrogen bonds interaction further give a 3D network.

\subsection{Magnetic properties}

Variable-temperature (300-2 K) magnetic susceptibilities of 1 have been measured on a crystalline sample in a field of 2000 Oe. Plots of $\chi_{\mathrm{M}}$ and $\chi_{\mathrm{M}} T$ vs $T$ are shown in figure 5, where $\chi_{\mathrm{M}}$ is the molar magnetic susceptibility for the $\mathrm{Sm}_{3}^{\mathrm{III}} \mathrm{Mo}_{2}^{\mathrm{V}}$ unit. As shown in figure 5 , the $\chi_{\mathrm{M}} T$ value is $0.525 \mathrm{~cm}^{3} \mathrm{~mol}^{-1} \mathrm{~K}$ at room temperature, which is lower than $1.020 \mathrm{~cm}^{3}$ $\mathrm{mol}^{-1} \mathrm{~K}$ expected for isolated three $\operatorname{Sm}$ (III) $(J=5 / 2$, $\left.g_{\mathrm{J}}=2 / 7\right)$ and two $\left.\operatorname{Mo}(\mathrm{V}) S=1 / 2\right)$ ions, the $\chi_{\mathrm{M}} T$ value deviate from at room temperature probably attributed the intrinsic characteristic of the $\mathrm{Sm}^{\mathrm{III}}$ ion owing to the first- and second-order Zeeman effect contributions of the ground $\left({ }^{6} \mathrm{H}_{5 / 2}\right)$ and first excited 

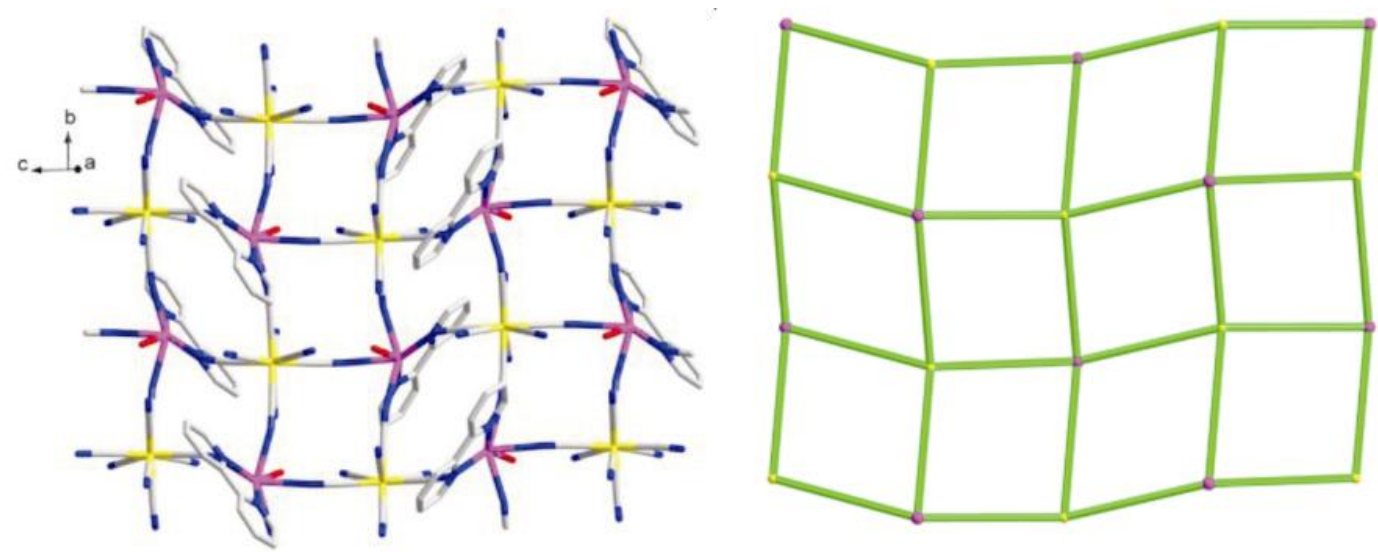

Figure 2. View of the square-grid pattern of the single layer for $\mathbf{1}$ (left). The topology of 1 belong to 4,4-net (right), the total Schläfli symbol is $\left\{4^{4}, 6^{2}\right\}\left\{4^{4}, 6^{2}\right\}$.

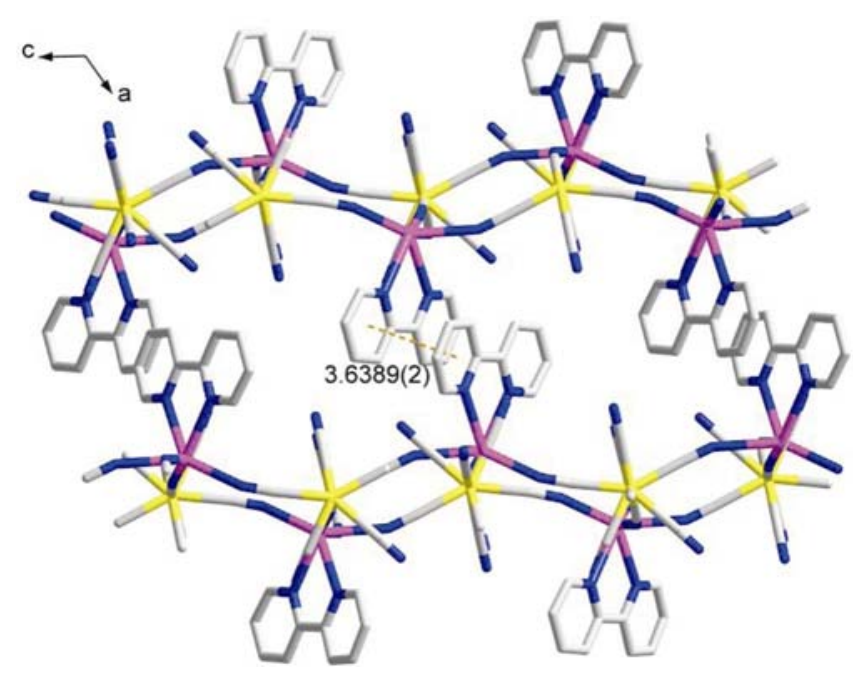

Figure 3. The interactions of $\pi-\pi$ stacks for two layers, and hydrogen atoms are omitted for clarity.

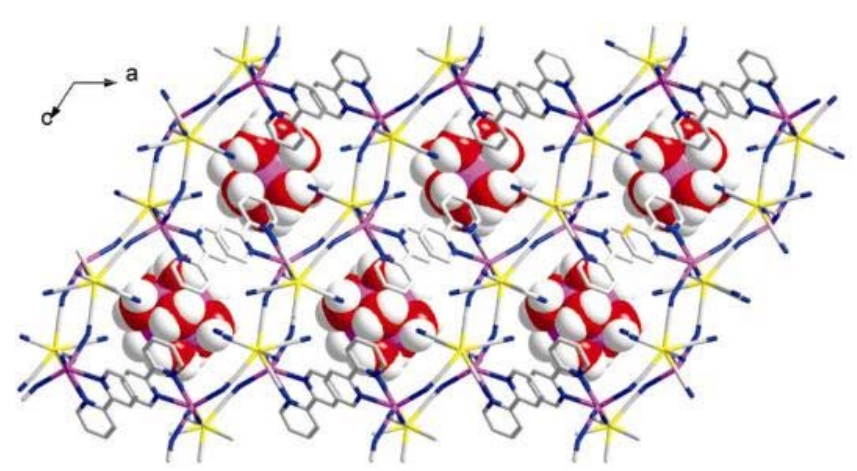

Figure 4. The guest molecules are buried in the holes which are filled with $\left[\mathrm{Sm}\left(\mathrm{H}_{2} \mathrm{O}\right)_{9}\right]^{3+}$ ions (space-filling spheres).

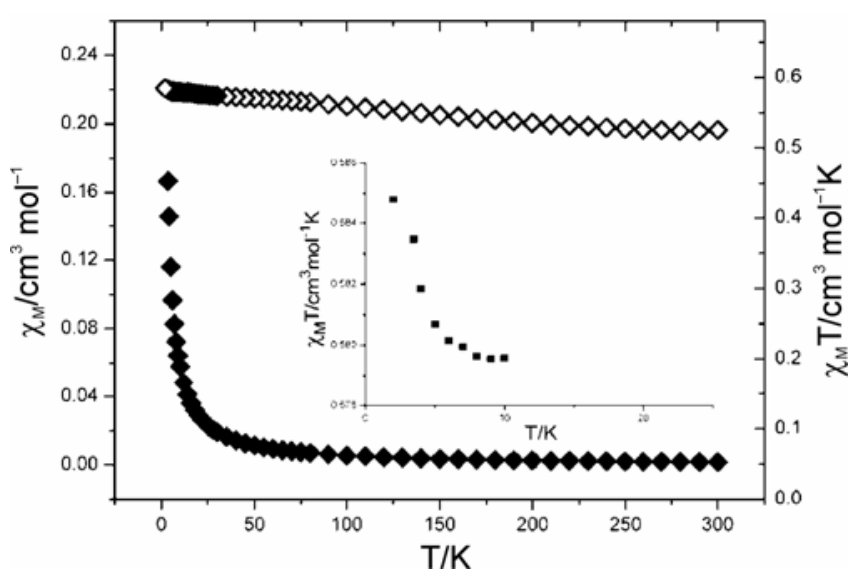

Figure 5. Plots of $\chi_{\mathrm{M}}(\diamond)$ and $\chi_{\mathrm{M}} T(\square)$ vs $T$ for 1 . The inset shows that the temperature dependence of $\chi_{\mathrm{M}} T$ for 1 at low temperature range $(2-10 \mathrm{~K})$.

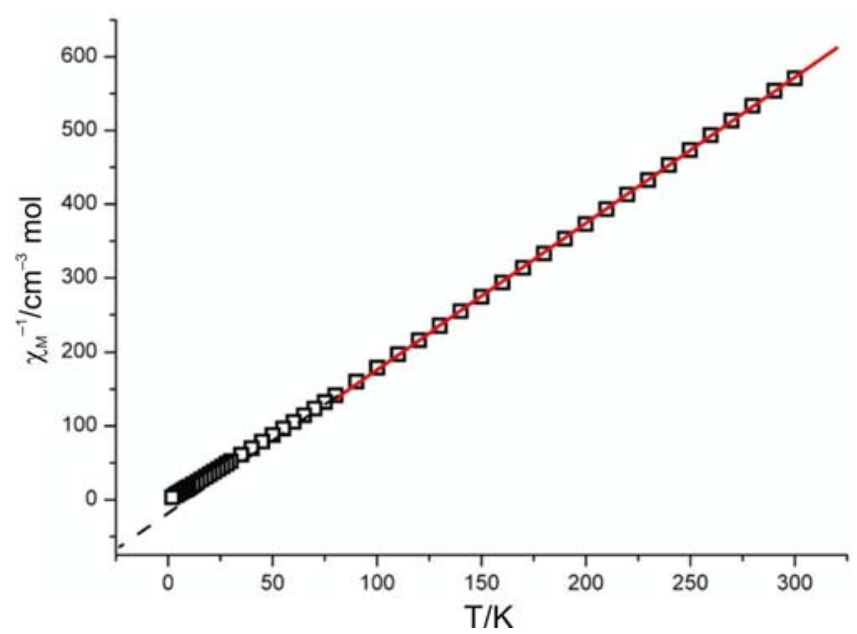

Figure 6. Plot of $\chi_{\mathrm{M}}{ }^{-1}$ vs $T$ for 1 . The solid line denotes the theoretical fit at $300-75 \mathrm{~K}$. 
$\left({ }^{6} \mathrm{H}_{7 / 2}\right)$ states of $\mathrm{Sm}^{\mathrm{III}}$ ion, while the thermal depopulation of Stark levels, which are close in energy, and thermally populated at room temperature due to the relatively low spin-orbit coupling effect. Therefore, the nature of the magnetic coupling between the $\mathrm{Sm}^{\mathrm{III}}-\mathrm{Mo}^{\mathrm{V}}$ ions cannot simply be determined from the low value of $\chi_{\mathrm{M}} T$ at room temperature (relative $1.020 \mathrm{~cm}^{3} \mathrm{~mol}^{-1} \mathrm{~K}$ expected for isolated ions), which should be due to the superposition of thermal depopulation of the low-lying excited states of $\mathrm{Sm}^{\mathrm{III}}$ ions magnetic interaction. As shown in figure 5, the $\chi_{\mathrm{M}} T$ product continuously increases with temperature decrease, implying a ferromagnetic coupling is observed in this system. Upon further cooling, a sharp increase is provided about $8 \mathrm{~K}$ (see inset figure 5 ), suggesting the onset of three-dimensional magnetic ordering, and the maximum value of $0.858 \mathrm{~cm}^{3}$ $\mathrm{mol}^{-1} \mathrm{~K}$ is reached at $2 \mathrm{~K}$. As shown in figure $6, \chi_{\mathrm{M}}{ }^{-1}$ vs $T$ obeys the Curie-Weiss law above $75 \mathrm{~K}$ with a positive Weiss constant $\theta=+11.02 \mathrm{~K}$, confirming further a ferromagnetic coupling between the paramagnetic ions through the magnetic $\left[\mathrm{Mo}^{\mathrm{V}}(\mathrm{CN})_{8}\right]^{3-}$ passage.

\section{Conclusion}

In summary, reaction of $\left(n-\mathrm{Bu}_{4} \mathrm{~N}\right)_{3}\left[\mathrm{Mo}^{\mathrm{V}}(\mathrm{CN})_{8}\right]$ with $\mathrm{Sm}\left(\mathrm{NO}_{3}\right)_{3} \cdot 6 \mathrm{H}_{2} \mathrm{O}$ in the presence of bpy affords a sheet-like bimetallic $\mathrm{Sm}^{\mathrm{III}}-\mathrm{Mo}^{\mathrm{V}}$ assembly. Magnetic results of the complex reveal that 1 obeys the CurieWeiss law with a positive Weiss constant $\theta=$ $+11.02 \mathrm{~K}$, confirming a ferromagnetic interaction between the $\mathrm{Sm}^{\mathrm{III}}$ and $\mathrm{Mo}^{\mathrm{V}}$ ions.

\section{Acknowledgements}

This project was supported by the National Natural Science Foundation of China (Nos. 20631030 and 20601014), and National Basic Research Program of China (973 Program, 2007CB815305).

\section{Supplementary material}

Crystallographic data for the structural analysis have been deposited with the Cambridge Crystallographic Data Centre, CCDC No. 690603. Copy of this information can be obtained free of charge from The Director, CCDC, 12 Union Road, Cambridge, CB2 1EZ, UK (fax: +44-1223-336-033; e-mail: deposit @ ccdc.cam.ac.uk or http://www.ccdc.cam.ac.uk).

\section{References}

1. Kahn O 1993 Molecular magnetism (New York: $\mathrm{VCH})$

2. Miller J S and Epstein A J 1994 Angew. Chem., Int. Ed. Engl. 33385

3. Miller J S 2000 Inorg. Chem. 394392

4. Gütlich P, Garcia Y and Woike T 2001 Coord. Chem. Rev. 219-221 839

5. Mallah T, Thiébaut S, Verdaguer $M$ and Veillet $P$ 1993 Science 2621554

6. Pejaković D A, Manson J L, Miller J S and Epstein A J 2001 Synth. Met. 122529

7. Ohba M, Ökawa H 2000 Coord. Chem. Rev. 198313

8. Ferlay S, Mallah T, Quahès R, Veillet P and Verdaguer M 1995 Nature 378701

9. Ohba M, Usuki N, Fukita N and Okawa H 1999 Angew. Chem., Int. Ed. 381795

10. Inoue $\mathrm{K}$, Imai $\mathrm{H}$, Ghalsasi $\mathrm{P} \mathrm{S}$, Kikuchi $\mathrm{K}$, Ohba $\mathrm{M}$, Okawa $\mathrm{H}$ and Yakhmi J V 2001 Angew. Chem., Int. Ed. 404242

11. Kou H Z, Gao S, Zhang J, Wen G H, Su G, Zheng R $\mathrm{K}$ and Zhang X X $2001 \mathrm{~J}$. Am. Chem. Soc. 12311809

12. Larionova J, Clérac R, Sanchiz J, Kahn O, Golhen S and Ouahab L $1998 \mathrm{~J}$. Am. Chem. Soc. 12013088

13. Larionova J, Kahn O, Golhen S, Ouahab L and Clérac $\mathrm{R} 1999 \mathrm{~J}$. Am. Chem. Soc. 1213349

14. Kaur Sra A, Andruh M, Kahn O, Golhen S, Ouahab L and Yakhmi J V 1999 Angew. Chem., Int. Ed. 38 2606

15. Li D F, Gao S, Zheng L M and Tang W X $2002 J$. Chem. Soc., Dalton Trans. $\mathbf{2 8 0 5}$

16. Withers J R, Li D F, Triplet J, Ruschman C, Parkin S, Wang G B, Yee G T and Holmes S M 2006 Inorg. Chem. 454307

17. Arimoto Y, Ohkoshi S, Zhong Z J, Seino H, Mizobe $Y$ and Hashimoto K 2002 Chem. Lett. 832

18. Li D F, Zheng L M, Zhang Y Z, Huang J, Gao S and Tang W X 2003 Inorg. Chem. 426123

19. Podgajny R, Desplanches C, Sieklucka B, Sessoli R, Villar V, Paulsen C, Wernsdorfer W, Dromzée Y and Verdaguer M 2002 Inorg. Chem. 411323

20. Song Y, Ohkoshi S, Arimoto Y, Seino H, Mizobe Y and Hashimoto K 2003 Inorg. Chem. 421848

21. Kashiwagi T, Ohkoshi S, Seino H, Mizobe Y and Hashimoto K 2004 J. Am. Chem. Soc. 1265024

22. Zhao H H, Shatruk M, Prosvirin A V and Dunbar K R 2007 Chem. Eur. J. 136573

23. Yoon J H, Kim H C and Hong C S 2005 Inorg. Chem. 447714

24. Li D F, Zheng L M, Wang X Y, Huang J, Gao S and Tang W X 2003 Chem. Mater. 152094

25. Korzeniak T, Podgajny R, Alcock N W, Lewiński K, Bałanda M, Wasiutyński T and Sieklucka B 2003 Polyhedron 222183

26. Ohkoshi S, Arimoto Y, Hozumi T, Seino H, Mizobe Y and Hashimoto K 2003 Chem. Commun. 2772

27. Podgajny R, Korzeniak T, Balanda M, Wasiutyński T, Errington W, Kemp T J, Alcock N W and Sieklucka B 2002 Chem. Commun. 1138 
28. Li D F, Gao S, Zheng L M, Yu K B and Tang W X 2002 New J. Chem. 261190

29. Korzeniak T, Stadnicka K, Rams M and Sieklucka B 2004 Inorg. Chem. 434811

30. Podgajny R, Chmel N P, Bałanda M, Tracz P, Gawel B, Zajac D, Sikora M, Kapusta C, Łasocha W, Wasiutyński T and Sieklucka B 2007 J. Mater. Chem. 17 3308

31. Korzeniak T, Stadnicka K, Pełka R, Balanda M, Tomala K, Kowalski K and Sieklucka B 2005 Chem. Commun. 2939

32. Herrera J M, Marvaud V, Verdaguer M, Marrot J, Kalisz M and Mathonière C 2004 Angew. Chem., Int. Ed. Engl. 435468

33. Lim J H, Kang J S, Kim H C, Koh E K, Hong C S 2006 Inorg. Chem. 457821

34. You Y S, Yoon J H, Lim J H, Kim H C, Hong C S 2005 Inorg. Chem. 447063

35. Ohkoshi $\mathrm{S}$, Ikeda $\mathrm{S}$, Hozumi $\mathrm{T}$, Kashiwagi $\mathrm{T}$ and Hashimoto K $2006 \mathrm{~J}$. Am. Chem. Soc. 1285320

36. Song $Y$, Zhan $\mathrm{P}$, Ren X M, Shen X F, Li Y Z and You X Z 2005 J. Am. Chem. Soc. 1273708

37. Herrera J M, Bleuzen A, Dromzée Y, Julve M, Lloret F and Verdaguer M 2003 Inorg. Chem. 427052

38. Ohkoshi S, Hamada Y, Matsuda T, Tsunobuchi Y and Tokoro H 2008 Chem. Mater. 203048

39. Visinescu D, Desplanches C, Imaz I, Bahers V, Pradhan R, Villamena F A, Guionneau P and Sutter J P 2006 J. Am. Chem. Soc. 12810202

40. Bonadio F, Gross M, Stoeckli-Evans H and Decurtins S 2002 Inorg. Chem. 415891

41. Lim J H, Yoon J H, Kim H C and Hong C S 2006 Angew. Chem., Int. Ed. Engl. 457424

42. Freedman D E, Bennett M V and Long J R 2006 Discussion of Faraday Soc. 2829
43. Larionova J, Gross $M$, Pilkington $M$, Andres $H$, Stoeckli-Evans H, Güdel H U and Decurtins S 2000 Angew. Chem., Int. Ed. Engl. 391605

44. Zhong Z J, Seino H, Mizobe Y, Hidai M, Fujishima A, Ohkoshi S and Hashimoto K $2000 \mathrm{~J}$. Am. Chem. Soc. 1222952

45. Lim J H, Yoo H S, Yoon J H, Koh E K, Kim H C and Hong C S 2008 Polyhedron 27299

46. Prins F, Pasca E, Jongh L J D, Kooijman H, Spek A L and Tanase S 2007 Angew. Chem. Int. Ed. 466081

47. Ikeda S, Hozumi T, Hashimoto $\mathrm{K}$ and Ohkoshi $\mathrm{S}$ 2005 Dalton Trans. 2120

48. Przychodzeń P, Pelka R, Lewiński K, Supe J, Rams M, Tomala K and Sieklucka B 2007 Inorg. Chem. 46 8924

49. Kosaka W, Hashimoto K and Ohkoshi S 2007 Bull. Chem. Soc. Jpn. 802350

50. Przychodzeń P, Lewiński K, Pełka R, Bałanda M, Tomala K and Sieklucka B 2006 Dalton Trans. 625

51. Ma S L, Ma Y, Liao D Z, Yan S P, Jiang Z H and Wang G L 2008 Chinese J. Inorg. Chem. 241290

52. Hozumi T, Ohkoshi S, Arimoto Y, Seino H, Mizobe Y and Hashimoto K 2003 J. Phys. Chem. B107 11571

53. Chelebaeva E, Larionova J, Guari Y, Sá Ferreira R A, Carlos L D, Almeida Paz F A, Trifonov A and Guérin C 2008 Inorg. Chem. 47775

54. Bok L D C, Leipoldt J G and Basson S S 1975 Z. Anorg. Allg. Chem. 41581

55. Sheldrick G M 1997 SHELXS-97 and SHELXL-97 (Germany: University of Göttingen)

56. Willemin S, Larionova J, Clérac R, Donnadieu B, Henner B, Le Goff X F and Guérin C 2003 Eur. J. Inorg. Chem. 1866 